REVIEW PROF-2148

\title{
HELICOBACTER PYLORI;
}

INFECTION AND TREATMENT

Miss. Faiza Naseer, Miss. Fatima Javed, Miss. Irum Irshad.

Article Citation

Naseer F, Javed F, Irshad I. Helicobacter pylori; infection and treatment. Professional Med J 2013;20(4): 489.494.

\section{INTRODUCTION}

Helicobacter pylori (H-pylori) is a gram negative spiral or curved microorganism which has been widely studied after his discovery, by human gastric biopsy, in 1983. Helicobacter pylori is commonly associated with the gastritis, peptic and duodenal ulcer as well as cancer of stomach. The most common disease caused by Helicobacter pylori is peptic ulcer'.

\section{EPIDEMIOLOGY}

$\mathrm{H}$-pylori is the most common pathogenic organism worldwide. Overall, almost $50 \%$ population of the world is infected by this organism, while the occurrence in some developing countries is as high as $80-90 \%$, whereas in the U.S., $35-40 \%$ of the population is infected ${ }^{2}$.

\section{TRANSMISSION OF H-PYLORI}

The exact route of transmission of $\mathrm{H}$ pylori is not fully known. H-pylori is mainly transmitted by oral ingestion and it is mostly transmitted within families in developed countries. In underdeveloped countries the prominent routes are saliva, feces and feco-oral route ${ }^{3}$.

\section{PATHOGENESIS}

The gastric mucosa shows well protection against bacteriological infection. $\mathrm{H}$. pylori with distinctive properties enter into the mucus and get attached to the epithelial cells. H. pylori have potential to escape from the defense mechanism of the body due to which it shows persistent colonization 4 .

After being entered to mucus layer, bacteria survive into the acidic $\mathrm{pH}$ which is due to hydrolysis of the urea by enzyme urease into ammonia and carbon dioxide. Urease activity is further regulated by Urel, pH-gated urea channel ${ }^{4}$.

Most of $\mathrm{H}$. pylori strains discharge a 95-kDa protein named as VacA. The VacA protein plays an important role in the pathogenesis of both peptic ulceration and gastric cancer. VacA gets attached to the epithelial cell membranes and forms voltage gated channels in membrane, thus prompting the release of urea, bicarbonates and nutrients from the host cells ${ }^{5}$. Vac within the epithelial cell membrane release proinflammatory cytokines due to which there is increase in the gastrin release and reduction in antagonist and inhibitor somatostatin. This in turns increases the acid secretion from the parietal cells and bicarbonates release is reduced which causes inflammation and damage that leads to ulcer and if untreated gastric carcinoma ${ }^{6}$. Vac also directly entered to the mitochondria where it releases cytochrom $\mathrm{c}$ which causes apoptosis and leads to carcinoma ${ }^{4}$.

\section{DIAGNOSIS}

Different invasive and non-invasive diagnostic test are performed for the detection of the $\mathrm{H}$. pylori infection. In non-invasive test for the initial diagnosis of the infection of $\mathrm{H}$. pylori urea breath test is performed. The specificity and sensitivity of the test is $90 \%$. The test should be performed after 4 weeks otherwise it will give false results. Urea test can be done for the children above 6 years. Another economical and mostly used non-invasive test is serologic testing. Its shows same specificity and sensitivity as urea breath test but this test is not reliable in young children. Stool antigen test 


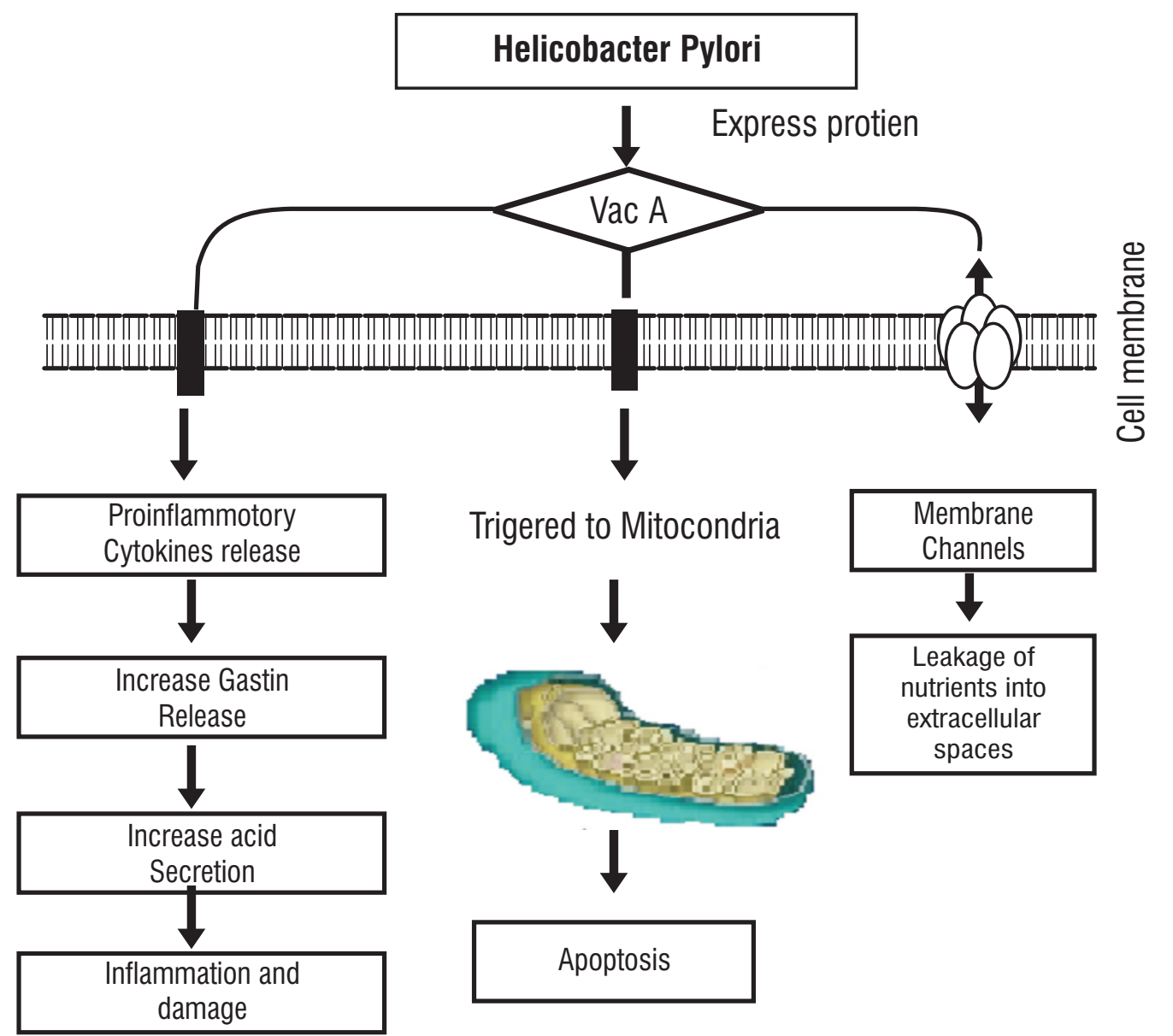

Figure: Pathogenesis of helicobacter pylori infection triggered by Vacl protein.

is also an alternative to urea breath test with $90 \%$ specificity and $89-98 \%$ sensitivity. Mostly stool test is performed for the follow up of infection. It is test of choice in almost all age of children. Invasive test like endoscopy is preferred in patient with severe symptoms like GIT bleeding as well as with the age more than 50 years. Antibiotic sensitivity culture test is not routinely performed for the initial diagnosis of the infection ${ }^{4}$.

\section{TREATMENT FOR H-PYLORI INFECTION}

\section{Triple Therapy}

For the treatment of $\mathrm{H}$. pylori infection first line recommended therapy is proton pump inhibitor (PPI)based triple therapy i.e. standard PPI dose twice daily + clarithromycin $500 \mathrm{mg}$ twice daily + amoxicillin $1000 \mathrm{mg}$ twice daily for 10 days $^{7}$. From different studies and analysis it is proven that triple therapy shows better results with twice daily dosing of proton pump inhibitor and clarithromycin is used twice in dose of $500 \mathrm{mg}$, rather than $250 \mathrm{mg}$. Although recommended as an alternative to patients who are penicillin allergic, the combination of clarithromycin and metronidazole should be discouraged as there is currently no effective salvage therapy if such a combination fails ${ }^{8}$. In triple therapy regimens 
clarithromycin substitution with other macrolides (e.g., erythromycin or azithromycin) is not recommended due to low efficacy ${ }^{9}$.

From recent studies, increased resistance to metronidazole and clarithromycin up to $42 \%$ and $20 \%$, respectively is shown and the cure rate of the standard triple therapy have fallen below the acceptable rate of $>80 \%$ in many regions ${ }^{10}$. So this therapy is not recommended as first line now a days except local susceptibility patterns show such a treatment regimen to be highly effective? .

\section{Quadruple Therapy}

Quadruple therapy is used as an alternative to the triple therapy. It includes PPI or H2-blocker (U.S. guidelines only) + bismuth + tetracycline + metronidazole that is used for 10 to 14 days. Quadruple therapy is used as first-line therapy for eradication of $H$. pylori. Formerly it was thought that the Dosing of Quadruple therapy is complex and less tolerated so triple PPI therapy was considered the first line therapy for $\mathrm{H}$. pylori infection treatment. Now quadruple therapy becomes first line treatment due to increased clarithromycin resistance. In standard quadruple therapy, the substitution of doxycycline for tetracycline is not recommended due to the lack of data ${ }^{7}$.

\section{Sequential Therapy}

Sequential therapy is a 10 days course which starts with PPI twice daily and amoxicillin $1000 \mathrm{mg}$ twice daily after which immediate 5 -day course of tinidazole 500 mg twice daily, and a PPI twice daily or clarithromycin $500 \mathrm{mg}$ twice daily, metronidazole 500 $\mathrm{mg}^{7}$. In Europe studies shows very high cure rate of this therapy i.e. $92 \%{ }^{11}$. From two different analyses it is proved that this therapy is effective in macrolide resistant H. pylori? ${ }^{7}$.

\section{Salvage Therapy}

An eradication rate for $\mathrm{H}$. pylori is ranging from $63 \%$ to 94\% in Asian and European populations are shown with salvage therapy. Salvage therapy is a regimen of levofloxacin-based triple therapy. A meta-analysis including four randomized, controlled trials showed that a 10-day levofloxacin-based triple therapy regimen had a superior eradication rate and was associated with fewer side effects compared to a 7day course of bismuth-based quadruple therapy. However, these results require validation in the North American population. Furthermore, the optimal levofloxacin dose $250 \mathrm{mg}$ twice daily vs. $500 \mathrm{mg}$ twice daily and duration of therapy either 7 or 10 days has yet to be determined. However, another meta-analysis did find a higher eradication rate with the 10-day over 7day regimen. Unfortunately, resistance to fluoroquinolones is rapidly increasing. Experts now recommend using fluoroquinolone therapy only when susceptibility data are available ${ }^{7}$.

\section{LOAD Therapy}

A new four-drug regimen shows great effectiveness with cure rate $88.9 \%$ with 10 days treatment and $89.4 \%$ with 7-day treatment in an open label study. LOAD therapy is levofloxacin $250 \mathrm{mg}$ daily with breakfast + omeprazole $40 \mathrm{mg}$ daily before breakfast + nitazoxanide 500 mg twice daily + doxycycline 100 mg daily at dinner. A larger randomized controlled trial is warranted to further evaluate the efficacy of this treatment regimen ${ }^{7}$.

- PPIs are taken before meal.

- Metronidazole recommended dose is $1500 \mathrm{mg} /$ day to overcome metronidazole resistance and getting better efficacy.

- Avoid cimetidine to reduce drug interaction.

- Lansoprazole+ Amoxicillin combination is used only in clarithromycin allergic or resistant patients ${ }^{7}$.

\section{PATIENT COUNSELLING}

Patient adherence is essential for successful eradication of H. pylori. Given the high pill burden, the 


\begin{tabular}{|c|c|c|c|c|}
\hline Drug 1 & Drug 2 & Drug 3 & Drug 4 & Duration \\
\hline $\begin{array}{l}\text { Esomeprazole } 20 \mathrm{mg} \\
\text { BID }\end{array}$ & $\begin{array}{l}\text { Clarithromycin } 500 \mathrm{mg} \\
\text { BID }\end{array}$ & $\begin{array}{l}\text { Amoxicillin 1gm } \\
\text { BID }\end{array}$ & - & 10 days \\
\hline $\begin{array}{l}\text { Lansoprazole } 30 \mathrm{mg} \\
\text { BID }\end{array}$ & $\begin{array}{l}\text { Clarithromycin } 500 \mathrm{mg} \\
\text { BID }\end{array}$ & $\begin{array}{l}\text { Amoxicillin 1gm } \\
\text { BID }\end{array}$ & - & $10-14$ days \\
\hline $\begin{array}{l}\text { Omeprazole } 20 \mathrm{mg} \\
\text { BID }\end{array}$ & $\begin{array}{c}\text { Clarithromycin } 500 \mathrm{mg} \\
\text { BID }\end{array}$ & $\begin{array}{l}\text { Amoxicillin 1gm } \\
\text { BID }\end{array}$ & - & 10 days \\
\hline $\begin{array}{l}\text { Rabeprazole } 20 \mathrm{mg} \\
\text { BID }\end{array}$ & $\begin{array}{l}\text { Clarithromycin } 500 \mathrm{mg} \\
\text { BID }\end{array}$ & $\begin{array}{l}\text { Amoxicillin 1gm } \\
\text { BID }\end{array}$ & - & 7 days \\
\hline $\begin{array}{l}\text { Ranitidine } 150 \mathrm{mg} \text { BID or } \\
\text { Famotidine } 40 \mathrm{mg} / \text { day or } \\
\text { Nizatidine } 300 \mathrm{mg} / \text { day } \\
\text { (single or divided doses) }\end{array}$ & $\begin{array}{c}\text { Metronidazole } 250 \mathrm{mg} \\
\text { QID }\end{array}$ & $\begin{array}{c}\text { Tetracyclin } 500 \mathrm{mg} \\
\text { QID }\end{array}$ & $\begin{array}{c}\text { Bismuth subsalicylate } \\
525 \mathrm{mg} \\
\text { QID }\end{array}$ & $10-14$ days \\
\hline $\begin{array}{l}\text { Omeprazole } 20 \mathrm{mg} \\
\text { BID }\end{array}$ & $\begin{array}{c}\text { Metronidazole } 375 \mathrm{mg} \\
\text { QID }\end{array}$ & $\begin{array}{c}\text { Tetracyclin } 375 \mathrm{mg} \\
\text { QID }\end{array}$ & $\begin{array}{l}\text { Bismuth subcitrate } \\
\text { potassium } 420 \mathrm{mg} \\
\text { QID }\end{array}$ & 10 days \\
\hline $\begin{array}{l}\text { Omeprazole } 40 \mathrm{mg} \\
\text { Once daily }\end{array}$ & $\begin{array}{l}\text { Clarithromycin } 500 \mathrm{mg} \\
\text { TID }\end{array}$ & - & - & 14 days \\
\hline $\begin{array}{l}\text { Lansoprazole } 30 \mathrm{mg} \\
\text { TID }\end{array}$ & $\begin{array}{l}\text { Amoxicillin } 1 \mathrm{gm} \\
\text { TID }\end{array}$ & - & - & 14 days \\
\hline \multicolumn{5}{|c|}{$\begin{array}{l}\text { FDA approved therapy for H-Pylori treatment } \\
\text { =twice daily } \quad \text { TID =thrice daily } \quad \text { QID =four times a day }\end{array}$} \\
\hline
\end{tabular}

increased frequency of administration and the prolonged duration of treatment, thorough understanding of the importance of completing the treatment regimen as prescribed is paramount. Nonadherence may be associated with awful outcomes, including treatment failure and antibiotic resistance. While adherence and proper administration of the regimen are crucial points of emphasis, patients should also be informed about potential treatmentrelated adverse effects. Advanced notification about common adverse effects as well providing suggestions for management may help to prevent premature discontinuation of the regimen.

- PPls are well tolerated, but headache, dizziness, nausea, diarrhoea, constipation and abdominal pain may occur. Patients should be instructed to take PPIs 30-60 minutes prior to a meal.

- Hypersensitivity to any component of the regimen may occur; however, this type of reaction is most likely with amoxicillin. Amoxicillin and clarithromycin are commonly associated with gastrointestinal (Gl) upset (nausea, vomiting, diarrhoea and abdominal pain). Amoxicillin may also be associated with headache and clarithromycin may also be associated with taste disturbances, such as a bitter or metallic taste in the mouth.

- Metronidazole elicits adverse effects similar to clarithromycin (i.e., Gl upset and metallic taste in the mouth) but also may be associated with a disulfiram-like reaction with alcohol consumption.

- In patients on warfarin initiating metronidazole, international internalized ratio (INR) elevations are common and require close monitoring.

- Tetracycline is associated with Gl upset, photosensitivity and tooth discoloration. Patients should be advised to wear sunscreen and avoid 
prolonged exposure to sunlight.

- Pregnant patients and children under the age of eight should not receive tetracycline. Certain medications and foods such as calcium, antacids, iron and milk, may reduce the absorption and, thus, the effectiveness of tetracycline. .

- Bismuth may cause Gl upset and darkening of the tongue and stool. Bismuth containing regimens should be used with caution in patients with renal impairment as accumulation may occur. Patients with aspirin (salicylate) sensitivity should avoid the subsalicylate form of bismuth.

\section{ROLE OF THE PHARMICIST}

Patient adherence is essential for successful eradication of $\mathrm{H}$. pylori. Providing patient education regarding adherence, proper administration of drug therapy and adverse effects is one of the most important roles that pharmacists provide in caring for patients with H-pylori. Additionally, pharmacists with access to prescription and/or medical records can review those records for prior clarithromycin and/or metronidazole use, which may increase the likelihood of antibiotic resistance and treatment failure.

Patient allergies identified during record review should be considered in choosing a regimen. For patients with allergies, regimens containing those antibiotics should be avoided. Other factors, such as drug interactions and contraindications to drug therapy, may influence treatment. Adverse effects, ease of administration and cost may also influence the choice of an initial eradication regimen. Finally, following completion of the eradication regimen, pharmacists may assist with monitoring for persistent or recurrent symptoms. Patients should be advised to contact a health care professional if symptoms persist or recur or if they experience alarm symptoms during treatment, such as blood in the stool. Pharmacists have the opportunity to fulfil many roles and have a valuable impact on patient care for $\mathrm{H}$. pylori.

\section{Copyright@ 26 Apr, 2013.}

\section{REFERENCES}

1. Magdalena K, Janice D, John W, Trevor J. Identification, characterization and localization of two flagellin species in Helicobacter pylori flagella. Journal of bacteriology. 1991;173(3):937-946.

2. Brian E, Lacy R, Brian E. Helicobacter pylori: Ulcers and More: The Beginning of an Era. The Journal of Nutritional Sciences 2001.

3. Robert $P$, Marjorie M. Epidemiology and diagnosis of Helicobacter pylori infection. British Medical Journal. 2001;323:920-922.

4. Sebastian S, Pierre M. Helicobacter pylori infection. New England Journal of Medicine. 2002;347:15.

5. Johannes G, Arnoud H, Ernst J. Pathogenesis of Helicobacter pylori Infection, Clinical Microbiology Review. 2006;19(3):449.

6. Anahita D, Emad M. Helicobacter Pylori, peptic ulcers and gastric cancer 2012.

7. Calvet $X$. Helicobacter pylori infection: treatment options. Digestion 73:119-128.

8. Silva FM, Eisig JN, Teixeira AC, et al. Short-term triple therapy with azithromycin for Helicobacter pylori eradication: low cost, high compliance, but low efficacy. British Medical Journal Gastroenterology. 2008;8:20.

9. Graham DY, Fischbach L. Helicobacter pylori treatment in the era of increasing antibioticresistance. British Medical Journal Gastroenterology. 2010;59:1143-1153.

10. Vaira D, Zullo A, Hassan C, et al. Sequential therapy for Helicobacter pylori eradication; the time is now! Therapeutic Advances in Gastroenterology. 2009:2:317-322. 
AUTHOR(S):

1. FAIZA NASEER

M.Phil Pharmacology

Hospital Pharmacist/Demonstrator

People Colony 1, Faisalabad.

2. FATIMA JAVED

M.Phil Pharmacology

People Colony 1, Faisalabad.

3. IRUM IRSHAD

M.Phil Pharmacology

Hospital Pharmacist/Demonstrator

Masoodabad, Faisalabad.
Correspondence Address:

Miss Faiza Naseer

M.Phil Pharmacology

Hospital Pharmacist/Demonstrator

Pc1, Faisalabad.

faiza.naseer@ymail.com
Article received on: 10/12/2012 Accepted for Publication: 15/04/2013 Received after proof reading: 21/05/2013

Mectronic submission saves time, postage costs and allows the manuscript
to be handled in electronic form throughout the publication process.
Accepts electronic submission of articles via e-mail, attachment in
MS Word format at following address:
info@theprofesional.com
editor@theprofesional.com
publication@theprofesional.com
for more details, visit us ;
www.theprofesional.com

